INTERNATIONAL BULLETIN OF BACTERIOLOGICAL NOMENCLATURE AND TAXONOMY

$\begin{array}{llll}\text { Volume } 5 & \text { October } 15,1955 & \text { No. } 4 & \text { pp. } 175-178\end{array}$

THEODOR THJ

$1885--1955$

\title{
An Appreciation
}

Theodor Thjotta, professor of medical bacteriology and serology at Oslo University, died suddenly on June 13, 1955, only 4 days before his 70th birthday. He was born in Sandnes in southwestern Norway in 1885. Originally he had planned a career as a naval officer, and in his early youth he sailed the seven seas in sailing ships for three years. Fortunately, one might say, he lost a part of a finger through an infection, and according to the strict requirements of those days he was rejected by the navy as medically unfit.

The same accident turned his interest towards medicine, and as soon as his ship called at a European port, he went home to complete his school education and to study medicine. In the course of his studies he went to sea again as a driftnet fisherman in the North Sea. Later on he was doctor on a whaling expedition to West Africa for two seasons. Throughout his life he remained something of a sailor at heart, and by a strange coincidence the book he had been reading on the night he died was entitled "A sailor goes ashore".

While in West Africa he had to tackle a bad epidemic of bacillary dysentery, and this made him interested in bacteriology.

From 1915 he studied bacteriology and pathology in Bergen under the well known pathologist Magnus Haaland, and he completed his training by a couple of years at the hospital for infectious diseases. In Bergen he mainly worked with dysentery bacilli, the theme of his thesis, and he arrived at a system of classification which differs little from the one in use today. In 1919 he was appointed chief of the newly established bacteriological laboratory of the Norwegian army, but first he went to the U.S.A. for further studies of bacteriology, mainly of the respiratory tract, at the Hospital of the Rockefeller Institute for Medical Research. In 1920 he returned to his laboratory in Oslo, where he worked until he was appointed professor of bacteriology and serology at Oslo University in 1935 .

Thjotta was a very active man with a strong will andabundant energy. Throughout his life he maintained a keen interest in research and published a large number of papers and 
books covering all aspects of medical microbiology. Only his more outstanding contributions to science can be mentioned here; his study of the dysentery bacilli (1917), his studies in collaboration with Avery on the growth requirements of the influenza bacilli (1921-24), his studies on tularemia in Norway (1930-31) with the first isolation of the organism in this part of the world, his studies on the bacteriology of fish (1942), on Leptotrichia (1944), on Weil's disease in Norway (1941) and others too numerous to mention.

All his papers were written in a clear and stimulating style, and always contained observations of scientific interest. Particularly in the early years, his papers had the double purpose of reporting new scientific results and of educating the Norwegian physicians, many of whom knew next to nothing about modern bacteriology and its practical value.

He was a gifted and inspiring teacher. Before his day, bacteriology in Norway was in a rather primitive stage, and the medical students learned only the bare and dry facts of classical bacteriology. Thjotta radically modernized the tuition and activated the students by practical courses, demonstrations, and discussions. He published a textbook covering the whole field of medical microbiology. The young physicians working under him also were inspired to great scientific effort, resulting in a very large number of scientific papers as well as ponderous theses. Furthermore, he managed to pursuade another man of the sea, Captain W. Wilhelmsen, owner of the W. Wilhelmsen Shipping Company, to donate funds for the building of a magnificent new bacteriological institute, which the university was very badly in need of.

He also was active on the international level, and took part in numerous congresses. He was a member of the International Committee on Bacteriological Nomenclature, of the Judicial Commission (class of 1959), of the Botanical Committee on Bacteria, the Subcommittee on the Family Neisseriaceae, and of the American Society of Bacteriologists (lately corresponding member). Furthermore, he was elected member of the Norwegian Academy of Science in Oslo (president of the Mathematics-Science Class in 1938), of the Copenhagen Medical Society, and of the Swedish Physicians' Society. He acted as one of the Norwegian editors of the Acta Pathologica et Microbiologica Scandinavica for many years. 
For his great services to Norwegian bacteriology he received the Fridtjof Nansen award from the Norwegian Academy of Science in Oslo in 1950, and a few months before his death he was created a commander of the St. Olav Order.

His greatest achievement may be that he successfully acted as a pioneer in a country which was "underdeveloped" in his field, and introduced all the new ideas which were developing. Thanks to his efforts bacteriology has a much better standing now in his country than it had when he started his work.

He was a very striking and colorful personality, a man of great gifts and great energy, and his life was busy and fruitful. His untimely death is regretted by many colleagues scattered throughout the world.

S. D. Henriksen 